\title{
NATURE AND TIMING OF BIOTIC RECOVERY IN ANTARCTIC BENTHIC MARINE ECOSYSTEMS FOLLOWING THE CRETACEOUS-PALAEOGENE MASS EXTINCTION
}

\author{
by ROWAN J. WHITTLE ${ }^{1 \star}$ D, JAMES D. WITTS ${ }^{2,4 \star}$, VANESSA C. BOWMAN $^{1}$, \\ J. ALISTAIR CRAME ${ }^{1}$, JANE E. FRANCIS ${ }^{1}$ and JON INESON ${ }^{3}$ \\ ${ }^{1}$ British Antarctic Survey, High Cross, Madingley Road, Cambridge, CB3 0ET, UK; roit@bas.ac.uk, vanwma@bas.ac.uk, jacr@bas.ac.uk, janefr@bas.ac.uk \\ ${ }^{2}$ School of Earth \& Environment, University of Leeds, Leeds, UK; jdwitts@unm.edu \\ ${ }^{3}$ Geological Survey of Denmark \& Greenland (GEUS), Copenhagen, Denmark; ji@geus.dk \\ ${ }^{4}$ Current address: Department of Earth \& Planetary Sciences, University of New Mexico, Northrup Hall, Yale Blvd NE, Albuquerque, NM 87131, USA \\ ${ }^{*}$ Corresponding authors
}

Typescript received 7 January 2019; accepted in revised form 15 April 2019

\begin{abstract}
Taxonomic and ecological recovery from the Cretaceous-Palaeogene (K-Pg) mass extinction 66 million years ago shaped the composition and structure of modern ecosystems. The timing and nature of recovery has been linked to many factors including palaeolatitude, geographical range, the ecology of survivors, incumbency and palaeoenvironmental setting. Using a temporally constrained fossil dataset from one of the most expanded $\mathrm{K}-\mathrm{Pg}$ successions in the world, integrated with palaeoenvironmental information, we provide the most detailed examination of the patterns and timing of recovery from the $\mathrm{K}-\mathrm{Pg}$ mass extinction event in the high southern latitudes of Antarctica. The timing of biotic recovery was influenced by global stabilization of the wider Earth system following severe environmental perturbations, apparently regardless of latitude or local environment.
\end{abstract}

Extinction intensity and ecological change were decoupled, with community scale ecological change less distinct compared to other locations, even if the taxonomic severity of the extinction was the same as at lower latitudes. This is consistent with a degree of geographical heterogeneity in the recovery from the $\mathrm{K}-\mathrm{Pg}$ mass extinction. Recovery in Antarctica was influenced by local factors (such as water depth changes, local volcanism, and possibly incumbency and pre-adaptation to seasonality of the local benthic molluscan population), and also showed global signals, for example the radiation of the Neogastropoda within the first million years of the Danian, and a shift in dominance between bivalves and gastropods.

Key words: mass extinction, Cretaceous, Palaeogene, Antarctica, biotic recovery.
MAss extinction events have profoundly affected the evolutionary history of life on Earth, and are topics of intense interest due to their links with rapid environmental change, and their longer term ecological and evolutionary effects (Raup \& Sepkoski 1982). The recovery of ecosystems following global extinction events is often characterized by a complex set of dynamics operating over an extended (100s of kyr to $>1$ myr) period (Chen \& Benton 2012). Recoveries cause changes in ecological strategy, differences in interactions between organisms, and shifts in the dominance of taxa in both marine and terrestrial environments (Hull 2015). There have been five major mass extinction events in the last 550 million years, the most recent of which occurred at the Cretaceous-Palaeogene $(\mathrm{K}-\mathrm{Pg})$ boundary 66 million years ago, with an estimated loss of $75 \%$ of marine and $50 \%$ of terrestrial species (Bambach et al. 2004; Alroy et al. 2008; Brusatte et al. 2015). This turnover has been convincingly associated with a large (c. 6-10 km diameter) bolide impact, which created the $180 \mathrm{~km}$ Chicxulub crater in the Gulf of Mexico (Schulte et al. 2010). Large Igneous Province volcanism, specifically the eruption of the Deccan Traps in India, is also thought to have contributed to latest Cretaceous and possibly earliest Paleocene environmental change and biological turnover (Schoene et al. 2019; Sprain et al. 2019). However, the degree to which this is the case is still vigorously debated (Courtillot \& Fluteau 2010; Keller et al. 2010; Schulte et al. 2010; Renne et al. 2013).

The severe, rapid and cascading environmental effects of the bolide impact may have included global darkness 
(Alvarez et al. 1980), rapid climatic changes due to injection of debris and volatiles into the atmosphere (Vellekoop et al. 2016; Brugger et al. 2017; Artemieva et al. 2017), collapse of food chains due to inhibition of photosynthesis (Sheehan et al. 1996), and potentially ocean acidification (Alegret et al. 2012). The extinction also led to changes in the global carbon cycle (D'Hondt et al. 1998; D'Hondt 2005; Esmeray-Senlet et al. 2015), which took over $1 \mathrm{myr}$ to recover to pre-boundary conditions (Birch et al. 2016). The biological and ecological reorganization that resulted from the K-Pg mass extinction had a profound influence on the nature and structure of modern ecosystems (Krug et al. 2009).

Discussion of the timing and nature of recovery following the K-Pg extinction has focused on developing models based on extinction selectivity, where traits shared by different organisms or clades can be shown to provide some advantage when compared to hypothesized short and long-term environmental effects of the mass extinction and its potential causal mechanism(s). Studies vary in terms of temporal and geographical scales, and attempts are often made to compare and link changes in both marine and terrestrial records to build a global picture. One of the earliest models for marine recovery emphasized the preferential survival of benthic detritus feeding organisms over those that were reliant on plant material or photosynthesis (Sheehan \& Hansen 1986; Aberhan et al. 2007) following evidence for a collapse in primary productivity (Arthur et al. 1987). Subsequent work has brought to light a variety of other biotic and abiotic factors which may play a role in extinction selectivity and preferential recovery of certain taxa following the K-Pg mass extinction. These include geographical distance from the impact site and/or palaeolatitude (Raup \& Jablonski 1993; Jiang et al. 2010; Donovan et al. 2016; Tosolini 2017; Lowery et al. 2018), palaeoecology (e.g. motility, tiering, feeding strategy; Sheehan \& Hansen 1986; Lockwood 2004), geographical range of a given species or clade (Jablonski \& Raup 1995; Longrich et al. 2012; Landman et al. 2014), the effect of incumbency, ecological interactions (Hull et al. 2011; Aberhan \& Kiessling 2014; Schueth et al. 2015) and differing palaeoenvironmental setting (e.g. onshore vs offshore, shallow vs deep water; Sessa et al. 2012; Aberhan \& Kiessling 2014; Jiang et al. 2018) in restoring communities and ecosystem function after the extinction.

Due to this complex array of different factors, an evolving view contends that the effects of the mass extinction on the Earth System were heterogeneous between different regions of the globe, and potentially among different clades and trophic groups, with local pre-boundary environmental conditions, and even chance playing a large role in recovery (Sepúlveda et al. 2009; Jiang et al. 2010; Hull et al. 2011; Sibert et al. 2014; Esmeray-Senlet et al. 2015; Donovan et al. 2016; Tosolini 2017). In this scenario, integrated and temporally constrained fossil datasets from individual localities tied to detailed palaeoenvironmental information are needed to assess the nature of extinction selectivity, and clarify the patterns and timing of recovery around the globe. Such analyses are rare in relatively shallow water continental shelf environments, as there is often a significant time gap over the $\mathrm{K}-\mathrm{Pg}$ boundary in these settings.

Here we integrate new stratigraphical collections of benthic molluscs (bivalves and gastropods, two of the most common taxa used to understand extinction and recovery in deep time due to their high preservation potential and range of ecological strategies) with palaeoenvironmental and new chronostratigraphic information from Seymour Island, Antarctica, to provide accurate constraints on the timing and nature of biotic recovery following the $\mathrm{K}-\mathrm{Pg}$ mass extinction event in the southern high latitudes.

\section{GEOLOGICAL SETTING}

Seymour Island, Antarctica, $64^{\circ} 15^{\prime} \mathrm{S}, 56^{\circ} 45^{\prime} \mathrm{W}$ (Fig. 1) is unique due to its high latitude setting in both the modern and Cretaceous-Paleocene interval (Lawver et al. 1992; Montes et al. 2010; Witts et al. 2016) and because it comprises one of the best exposed and most stratigraphically complete Cretaceous-Paleocene sedimentary sequences anywhere in the world. A robustly dated (Bowman et al. 2012, 2013, 2016; Tobin et al. 2012; Witts et al. 2015, 2016), highly expanded stratigraphical succession is contained within the López de Bertodano Formation (LBF) and overlying Sobral Formation (SF) (Bowman et al. 2013, 2016; Witts et al. 2015, 2016). The composite stratigraphical section through these units presented herein comprises an essentially continuous record of life in the polar seas from the early Maastrichtian (c. $69 \mathrm{Ma}$ ) through to the Danian (c. $65 \mathrm{Ma})$.

The K-Pg boundary occurs within the upper portion of the $1100 \mathrm{~m}$-thick LBF, within a glauconite-rich unit which forms the contact between informal lithostratigraphic units Klb9 and Klb10 (Macellari 1988) (herein referred to as LB9 and LB10) (Elliot et al. 1994; Bowman et al. 2012). Numerous detailed sedimentary analyses have previously been applied to this succession to decipher local palaeoenvironments accurately (Macellari 1988; Olivero et al. 2008; Schoepfer et al. 2017). These indicate that the LBF represents a series of palaeoenvironments, ranging from estuarine to shallow marine (mid-shelf) (Macellari 1988; Olivero et al. 2008; Olivero 2012). However, both the latest Maastrichtian and early Palaeogene sediments were deposited in a similar mid-shelf environment (Macellari 1988; Olivero 2012). Macellari (1988) suggested the presence of a sudden 
FIG. 1. A, map of Antarctic Peninsula, showing location of Seymour Island. B, geology of Seymour Island, with the location of the three section lines along which macrofossils were collected, 1 in 2010, 2 in 1999, and 3 in 2006. The K-Pg boundary (66.04 Ma; Renne et al. 2013), shown in red, runs NE to SW across the island. Redrawn from Montes et al. (2010) and Witts et al. (2016).

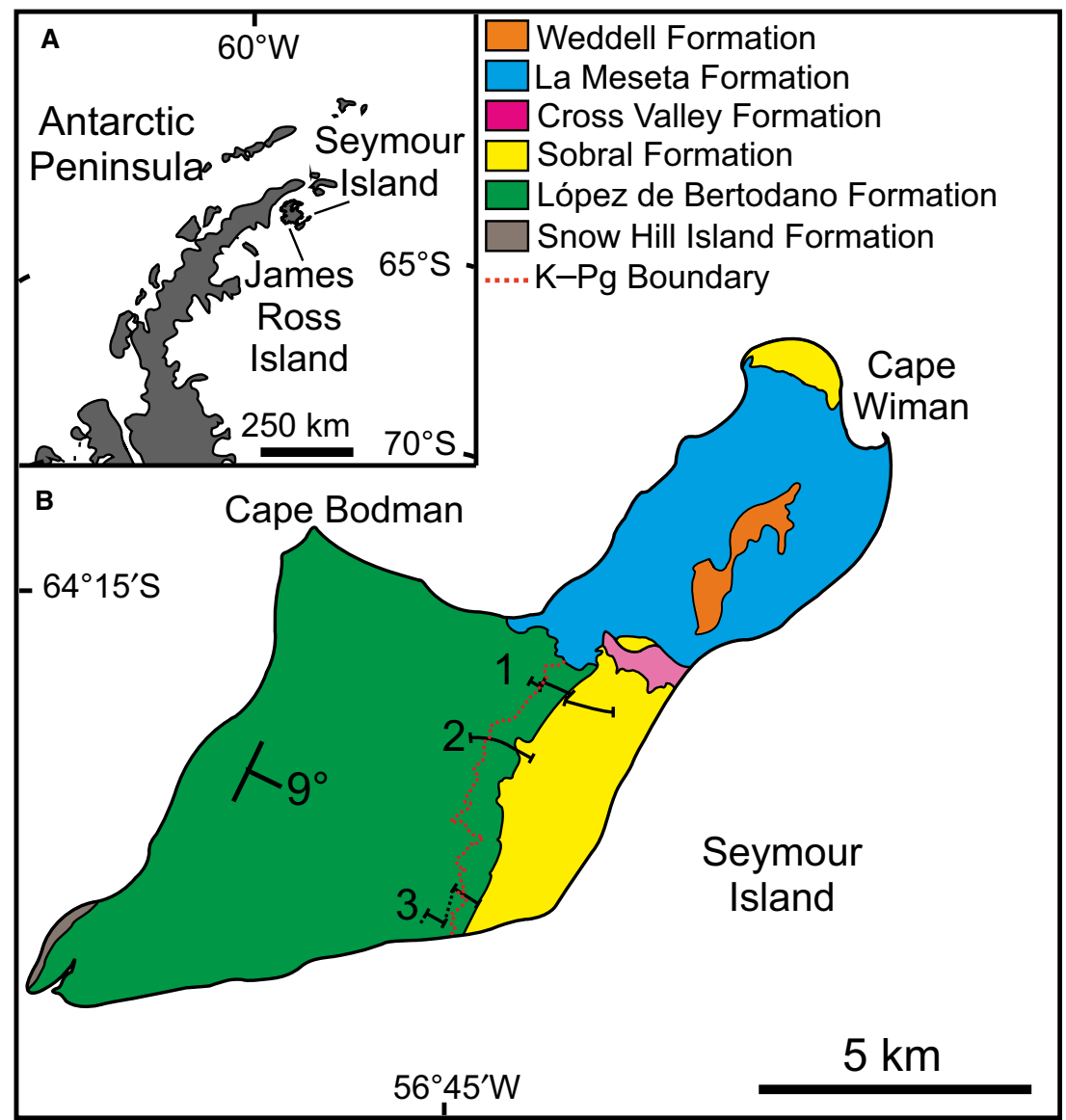

regression, and possible minor depositional hiatus 25$30 \mathrm{~m}$ below the K-Pg boundary. However, Tobin (2017) stated that there is little sedimentological variation between LB9 and LB10, and Crame et al. (2004) noted that they saw no evidence for a hiatus between these units. As a result, changes to diversity, abundance and ecology of fossil taxa in this interval are likely to be related to the aftermath of the mass extinction, rather than any distinct local change in environment.

The contact between LB10 and the overlying SF is an unconformable sequence boundary (Macellari 1988), with a shift in the local palaeoenvironment from mid-shelf to prodelta. Bowman et al. (2016) noted no appreciable change in the dinoflagellate cyst flora across the LB10/SF boundary, and this, as well as the age model for the section, showed that there was not a significant time gap (Bowman et al. 2016). However, there is a clear change in environment reflected in the sedimentology of the SF. This shows an overall regressive trend, reflecting eastward progradation of a marine delta with sediments originating from the Antarctic Peninsula more than $100 \mathrm{~km}$ to the west (Macellari 1988; Marenssi et al. 2012). The SF is mostly Danian in age (Tobin et al. 2012; Bowman et al. 2016).
A robust age model now exists for this composite LBF and SF sequence (Bowman et al. 2012, 2013, 2016; Tobin et al. 2012; Witts et al. 2015, 2016), which can be correlated with the international timescale using magnetostratigraphy and radiometric dates. This indicates the section is highly expanded compared to many onshore $\mathrm{K}-\mathrm{Pg}$ successions at lower latitudes.

\section{MATERIAL AND METHOD}

Field collecting strategy

Analyses were carried out on benthic mollusc collections made systematically through $550 \mathrm{~m}$ of logged sedimentary section lines over three separate field seasons (1999, 2006 and 2010) (Fig. 1B). The 1999 data were collected from section line DJ.953 made through LB9 and LB10 of the LBF in central Seymour Island (Crame et al. 2004, 2014). Fossils from the 2006 field season were collected along section line D5.251 in LB9 LBF, LB10 LBF and the SF. A third section was logged in the northern part of Seymour Island in the 2010 British Antarctic Survey (BAS) field season through the uppermost of LB9 LBF, LB10 LBF 
(D9.205-207) and the SF (D9.209 and D9.210) (Bowman et al. 2016) (Fig. 1).

Data from 1999 and 2010 were collected systematically, using the same methodology. The 2006 data was collected by a different team; from shorter collecting horizons, at more regular intervals (see Whittle et al. 2019, suppl. data). Occurrences for the 1999 and 2006 collections are given in Witts et al. (2016). New occurrence data presented herein from the 2010 collection is given in Whittle et al. (2019, fig. 1).

For the purposes of this study, primarily concerned with the biotic recovery following the $\mathrm{K}-\mathrm{Pg}$ mass extinction, the uppermost $200 \mathrm{~m}$ of the complete Late Cretaceous dataset was included, the lower units of the LBF having been studied in detail in Witts et al. (2016). Fossil specimens are curated and stored in the BAS collections, Cambridge. Fossil identifications were based on revised molluscan taxonomy (Beu 2009; Crame et al. 2014; Witts et al. 2016).

\section{Fossil data analysis}

Mass extinctions affect a variety of aspects of ecosystem structure and function (Hull \& Darroch 2013); therefore, analyses were carried out at several different scales ranging from individual fossil occurrences to whole community comparisons across the $\mathrm{K}-\mathrm{Pg}$ boundary.

Quantitative diversity metrics were calculated from abundance data in individual sampling horizons for each species from the 1999 and 2010 BAS field collections, which were collected using the same methodology. Shannon diversity $\left(H^{\prime}\right)$ was calculated using Primer v.6 (Clarke \& Warwick 2001). Additional diversity metrics for the 2006 field collection are available in Whittle et al. (2019, fig. 2).

To assess initial recovery, occurrences of species in sampling horizons within LB10 were also illustrated from the three BAS collections, as well as occurrences taken from the literature (Zinsmeister 1998; Stilwell et al. 2004) mentioned above. For diagrammatic purposes the mid points of collecting horizons were plotted.

The first and last occurrence data of species from the 1999, 2006 and 2010 collections, with additional data from the study of Zinsmeister (1998) and some stratigraphically constrained species ranges from Stilwell et al. (2004) (correlation to BAS section lines described in Crame et al. (2014) and Witts et al. (2016)), were used to construct a composite range chart. Several stratigraphic tie points were used to correlate different sedimentary section lines, such as glauconite beds in the LBF, and the base of the SF. Changes in stratigraphic bin size were accounted for by taking the base of the stratigraphic bin in which a species first occurred as the first appearance, and the top of the stratigraphic bin in which a species last occurred as the last appearance (as in Witts et al. 2016). These were plotted against the stratigraphy and age model from Bowman et al. (2016). The ecological categories of tiering, feeding and motility from Bambach et al. (2007) were combined to provide a mode of life for each species.

To examine broader ecological patterns, proportional taxonomic richness (based on the number of species) and proportional abundance (based on specimen numbers) for tiering, feeding and motility categories were calculated using all datasets for three binned intervals and shown for LB9, LB10 and the SF.

Ecological community structure for the Cretaceous and Palaeogene was analysed using modes of life for species and abundance data in individual sampling horizons, from the three BAS field collections (1999, 2006 and 2010). For abundance, sampling horizons with at least 22 individuals were used. These were analysed below and above the K-Pg boundary, as in the methodology outlined by Aberhan \& Kiessling (2015) to allow for direct comparison with data from other sites at lower latitude. Non-parametric multidimensional scaling (nMDS) was performed using a Bray-Curtis similarity index to visualize patterns in the multivariate data using Primer v.6 (Clarke \& Warwick 2001). The significance of the stratigraphic groupings (LB9 Cretaceous, LB10 Palaeogene, SF Palaeogene) based on ecology for the species numbers and abundance data was assessed using the ANOSIM test. The similarity percentages routine (SIMPER) was used for the ecology based on species numbers and abundance data to determine which ecological strategies were responsible for the greatest similarity within the stratigraphic periods.

\section{RESULTS}

Timing of taxonomic and ecological recovery in Antarctica based on stratigraphic data

Our data show that the extinction event in Antarctica is associated with a drop in both standing species richness of benthic molluscs and quantitative diversity metrics (Fig. 2) coincident with the $\mathrm{K}-\mathrm{Pg}$ boundary, defined by dinoflagellate cyst biostratigraphy (Elliot et al. 1994; Bowman et al. 2012, 2016), and a small iridium (Ir) anomaly in a parallel section (Elliot et al. 1994). The extinction interval on Seymour Island is several metres thick (1007.5-1013 $\mathrm{m}$ in the composite stratigraphic section), including a layer with disarticulated and articulated fish debris (Zinsmeister 1998), with the upper limit here coincident with the last appearance of Cretaceous holdover taxa, as defined by Witts et al. (2016) (Fig. 3). Due to the large difference in sampling strategy, diversity analysis through the section appeared dramatically different in the 
2006 collection, highlighting the importance of standardizing sampling methods for comparing different data sets (see Whittle et al. 2019, fig. 2).

Taxonomic recovery from the extinction initiated rapidly in the earliest Palaeogene, with the occurrence of three new species of benthic mollusc immediately above the extinction horizon at the base of LB10 (1007.5 $\mathrm{m}$ in the composite section) (Figs 2, 3). There is no indication for any size reduction (i.e. a 'Lilliput effect') in the benthic molluscan fauna above the $\mathrm{K}-\mathrm{Pg}$ boundary in Antarctica. Both diversity and standing species richness of the benthic molluscan fauna increase during LB10 (Fig. 2). A total of four new taxa appear throughout LB10, with a concentration of first occurrences and appearance of three new species towards the top of the unit, stratigraphically $c .50 \mathrm{~m}$ above the extinction interval (Fig. 4).
The most dramatic ecological change in benthic molluscan faunas is a distinct shift in tiering. Infaunal taxa preferentially survived and proliferated immediately following the extinction event, in LB10, and apart from a single specimen of the semi-infaunal bivalve Pinna, the only molluscs in this ecological category occur in a 40 m-thick interval in the early Paleocene of LB10 (Fig. 3). These taxa were generally facultatively motile shallow infaunal suspension feeders or slow motile shallow infaunal surface deposit feeders (Fig. 3). The taxonomic richness of species each ecological category remained similar over the $\mathrm{K}-\mathrm{Pg}$ boundary (Fig. 5A) but the abundance of specimens within each ecological category changed dramatically over the boundary (Fig. 5B). Infaunal organisms dominated on abundance, but not on species numbers. This is because there was an
A

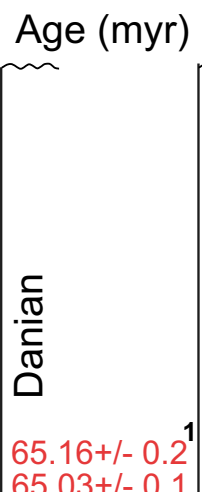

$65.03+/-0.1$

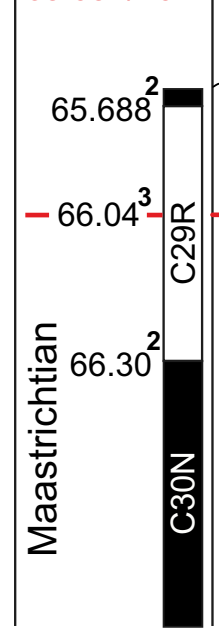

B

Height $(m)$

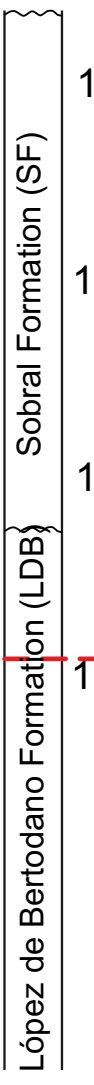

C

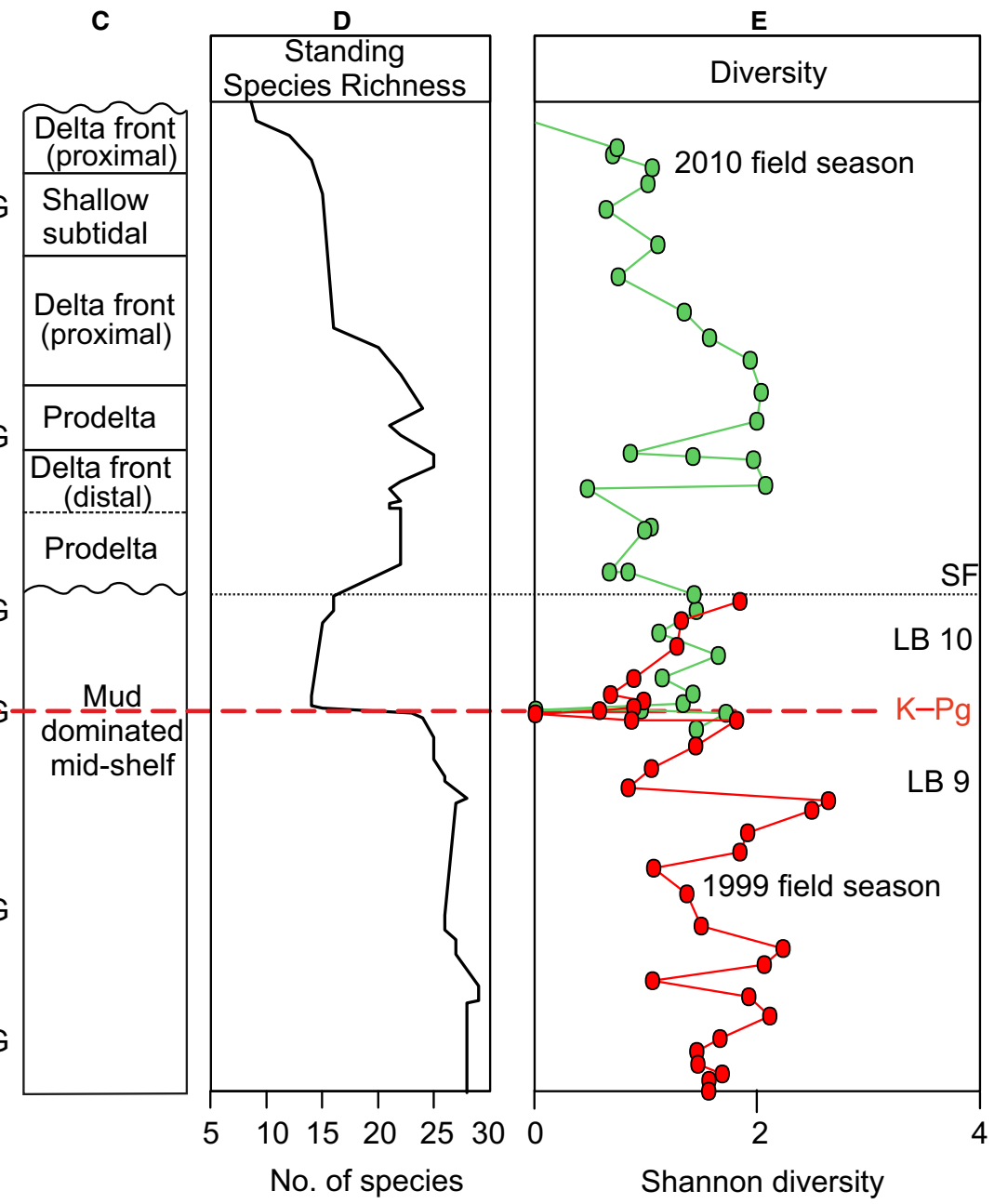

FIG. 2. Benthic molluscan standing species richness and diversity metrics. A, age model (Bowman et al. 2013, 2016); 1, U-Pb zircon dates from airfall tuff beds (Bowman et al. 2016); 2, dates for magnetochron boundaries (Ogg et al. 2012); 3, date for the K-Pg boundary (Renne et al. 2013). B, lithostratigraphy; G, glauconitic horizon. C, palaeoenvironmental setting. D, standing species richness. E, Shannon $\left(H^{\prime}\right)$ diversity for the 1999 and 2010 field collections; the 2006 field collection had a different sampling strategy; diversity for this is shown in Whittle et al. (2019, fig. 2). 


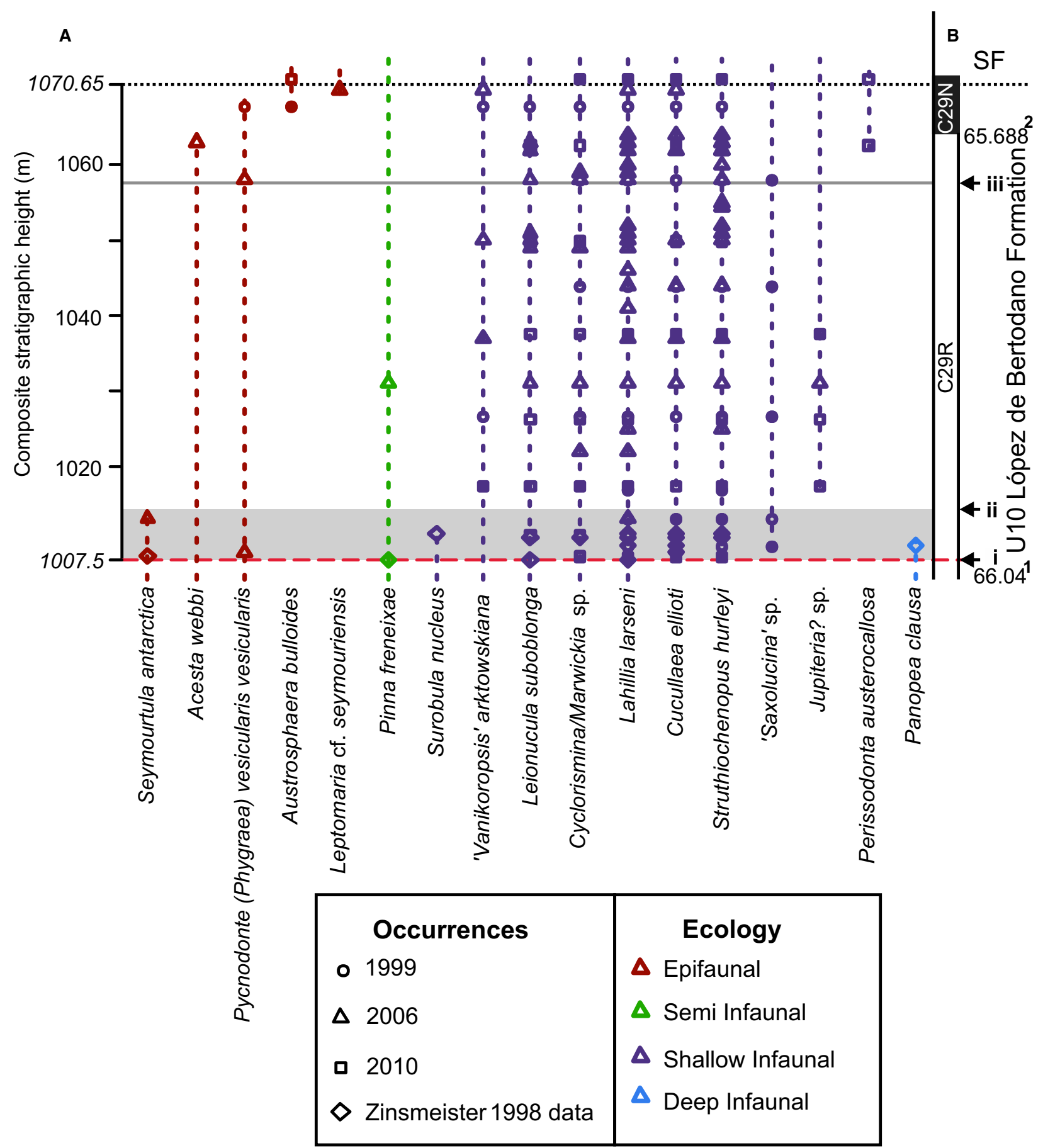

FIG. 3. Occurrences and palaeoecology of benthic molluscan species in LB10 of the LBF. A, point shape refers to collection, colour refers to ecology (tiering), and dashed lines indicate ranges (for additional versions of this figure relating to feeding strategy and motility see Whittle et al. 2019, figs 3-4). B, stratigraphy and age model; i, K-Pg boundary located at a height of $1007.5 \mathrm{~m}$ in the composite section, defined by dinoflagellate biostratigraphy (Bowman et al. 2012, 2013) and appearance of Ir anomaly in parallel section (Elliot et al. 1994); ii, last appearance datum of Cretaceous holdover taxa, defining the top of the extinction interval on Seymour Island (Witts et al. 2016); iii, stratigraphic horizon where epifaunal taxa return to the composite section; 1, date for the K-Pg boundary (Renne et al. 2013); 2, date of C29R/29N reversal (Ogg et al. 2012). 


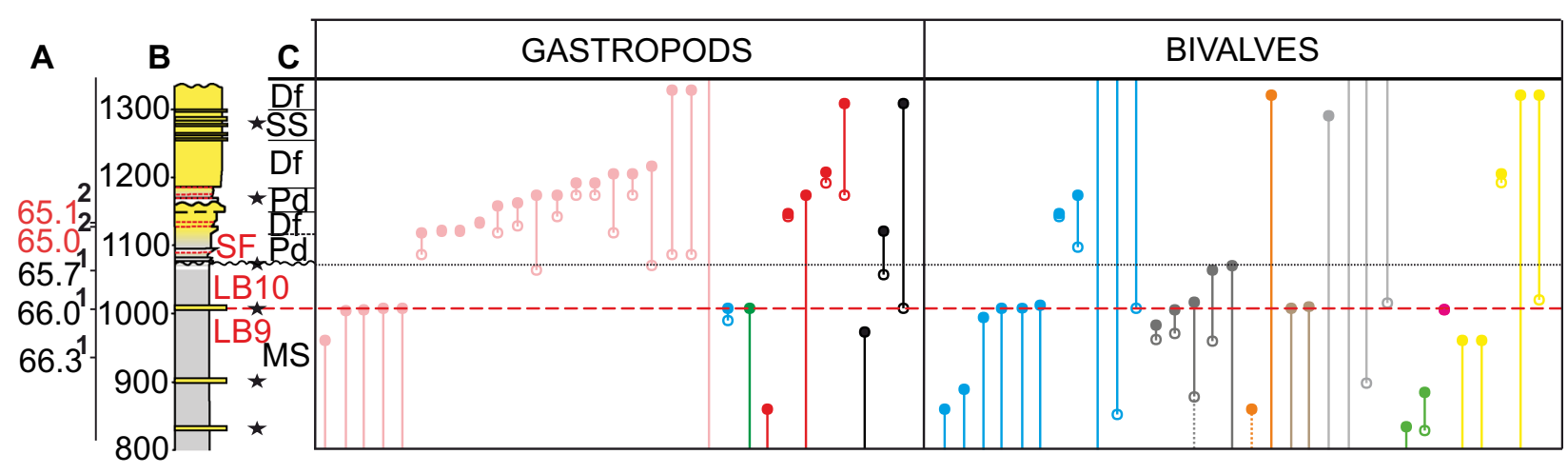

- Slow motile epifaunal carnivore [21]

- Facultatively motile unattached shallow infaunal suspension feeder [12]

- Slow motile epifaunal deposit feeding (surface) [1]

- Slow motile shallow infaunal carnivore [5]

- Slow motile shallow infaunal deposit feeding (surface) [3]

- Stationary attached epifaunal suspension feeder [5]

- Stationary attached semi infaunal suspension feeder [2]

- Facultatively motile unattached deep infaunal suspension feeder [2]

- Slow motile shallow infaunal deposit feeding (mining) [4]

- Facultatively motile unattached epifaunal suspension feeder [2]

- Facultatively motile attached epifaunal suspension feeder [1]

- Facultatively motile unattached deep infaunal chemosynthetic [5]

O First appearance

- Last appearance

..... K-Pg Boundary

FIG. 4. Composite Stratigraphic Range for benthic molluscan taxa in the upper two units of the LBF (LB9 and LB10) and SF. A, age model; B, lithostratigraphy; star, glauconitic horizon; age dates: 1, magnetochron reversals (Gradstein et al. 2012; Tobin et al. 2012); 2, U-Pb dates from ash horizons in the SF (Bowman et al. 2016). C, palaeoenvironmental setting: Df, delta front; MS, mid-shelf; Pd, prodelta; SS, shallow subtidal. Lines on range chart are coloured according to mode of life of benthic molluscan taxa, number in brackets following mode of life indicates number of species. Data from 1999, 2006, 2010 BAS field collections, supplemented by Zinsmeister (1998) and Stilwell et al. (2004), occurrences detailed in Crame et al. (2014). Whittle et al. (2019, fig. 5) shows taxon names for ranges.

abundance of specimens within a small number of species.

The reappearance of epifaunal species coincides with an increase in the appearance of new taxa $c .50 \mathrm{~m}$ above the $\mathrm{K}-\mathrm{Pg}$ boundary on Seymour Island (Figs 3, 4). This horizon can be dated to $c .320000 \mathrm{yr}$ after the extinction based on correlation to the base of magnetochron C29N (Ogg et al. 2012; Tobin et al. 2012; Witts et al. 2016), and was more recently precisely dated to $328000 \pm$ $15000 \mathrm{yr}$ after the mass extinction by Sprain et al. (2018). A further increase in standing species richness occurs at the base of the SF (Fig. 2), potentially related to the distinct change in palaeoenvironment. Evidence for broader recovery of the benthos is present at this level, with the return of echinoid spines and serpulid worm tubes (Rotularia), which were abundant below the $\mathrm{K}-\mathrm{Pg}$ boundary in LB9 (Macellari 1988; Witts et al. 2016; RJW unpub. data). Although species richness of benthic molluscs continued to increase above the sequence boundary, it does not recover to pre-extinction values in the basal SF. The highest standing species richness values occur between $c .1140$ and $1150 \mathrm{~m}$ in the composite section, coincident with the highest Paleocene diversity values (Fig. 2). At this horizon, there is a radiation of gastropod species, many with short ranges. Unlike species richness, diversity values do return to values comparable to the late Maastrichtian. Recently published $\mathrm{U}-\mathrm{Pb}$ dating of ash beds within this interval indicate it was deposited $c$. $65 \mathrm{Ma}$ (Bowman et al. 2016), placing this recovery of species richness and diversity values 1 myr after the mass extinction (Renne et al. 2013).

Stratigraphically above this level, evidence for further recovery is complicated by localized environmental changes in the SF. Species richness and diversity decrease 


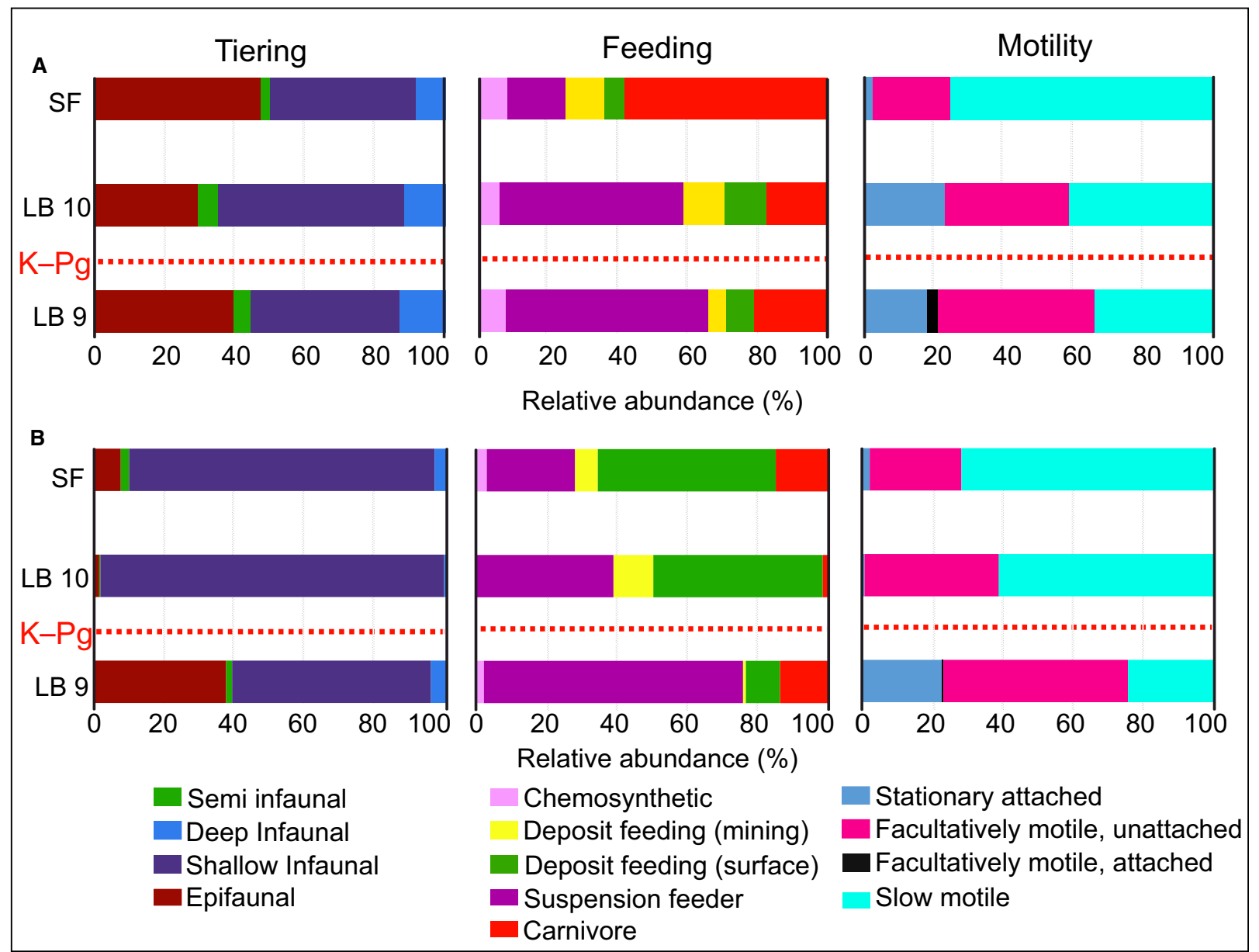

FIG. 5. A, proportional taxonomic richness for tiering, feeding and motility categories based on species numbers in LB9, LB10 and the SF. B, proportional taxonomic abundance based on specimen numbers, for tiering, feeding and motility categories based on specimen numbers in LB9, LB10 and the SF.

to values lower than those immediately following the $\mathrm{K}-\mathrm{Pg}$ mass extinction (Fig. 2), coincident with evidence that the depositional environment shallowed due to delta progradation (Bowman et al. 2016). Many of the new benthic molluscan taxa, which occur in the lower portion of the SF also have short stratigraphic ranges (Fig. 4).

Community scale changes in ecology over the $\mathrm{K}-\mathrm{Pg}$ boundary in Antarctica

Overall, the benthic molluscs in this study occupied 12 different modes of life (Fig. 4). Two of these modes of life are present in the Maastrichtian, but do not occur in the Paleocene of Antarctica. There was no significant difference in taxonomic richness in ecological categories across the $\mathrm{K}-\mathrm{Pg}$ boundary, but there was a substantial change in taxonomic richness from the LBF into the SF (Fig. 5A). Conversely, there was a change in the abundance of specimens within each ecological category, showing a marked change in dominance of ecological types over the $\mathrm{K}-\mathrm{Pg}$ boundary, with less of a change over the LBF/SF boundary (Fig. 5B).

The ecological composition of some sampling horizons of the Antarctic Maastrichtian community showed some similarity with Danian horizons, causing a degree of overlap in nMDS analyses (Fig. 6). There was more ecological similarity between the two time periods based on taxonomic richness (Fig. 6A) than there was specimen abundance (Fig. 6B) in the different ecological categories. However, as a whole, the ecological composition of the Maastrichtian was statistically significantly different to the Danian for both datasets $(R=0.244$ for species data, $R=0.452$ for abundance data; results significant at $p=0.001)$. Using the same methodology for abundance data from North and South American localities, Aberhan \& Kiessling (2015) documented distinct shifts in ecospace utilization at four sites located at different palaeolatitudes over 
the K-Pg boundary (Aberhan \& Kiessling 2015, fig. S3). In contrast to our results they showed discrete, non-overlapping groups when comparing convex hull surfaces of Maastrichtian and Danian samples from their localities. There was no clear distinction in ecology between the two Palaeogene horizons (LB10 and SF), despite the apparently significant change in the environment of deposition (Fig. 6).

There were more modes of life in the Antarctic Cretaceous community than the Palaeogene (Whittle et al. 2019, table 1). Within the Cretaceous community, similarity between sampling horizons was driven by stationary attached epifaunal suspension feeders and slow motile epifaunal carnivores, in addition to the pervasively dominant facultatively motile unattached shallow infaunal suspension feeders. This mode of life was a dominant component of LB9, LB10 and the SF (Whittle et al. 2019, tables 1-3), and is probably responsible for the similarity between some individual Cretaceous and Palaeogene samples. The Paleocene communities in LB10 and the SF share a high dominance of slow motile shallow infaunal surface deposit feeders (i.e. Struthiochenopus) (Whittle et al. 2019, tables 2-3).

\section{DISCUSSION}

The timing of recovery following the mass extinction

It has been demonstrated that the $\mathrm{K}-\mathrm{Pg}$ mass extinction in the southern hemisphere oceans was rapid, and comparable in severity to the northern hemisphere in terms of taxonomic loss of benthic molluscan faunas (Aberhan \& Kiessling 2014; Witts et al. 2016). Tobin (2017) recently argued that fossil data from Seymour Island is consistent with a two-phased extinction in Antarctica. However, these analyses were based on patterns of last appearance datums within individual sedimentary section lines. Our composite standing species and diversity data from multiple sections support a single, rapid and severe extinction event at the $\mathrm{K}-\mathrm{Pg}$ boundary, that is related to the Chicxulub impact (Fig. 2).

Any changes brought about by the Chicxulub impact event (e.g. transient cooling, global darkness, local expansion of anoxic waters; Zinsmeister 1998; Sosa-Montes De Oca et al. 2013; Vellekoop et al. 2016, 2018; Brugger et al. 2017) were probably extremely short-lived. Palaeoclimate data derived from marine (Tobin et al. 2012; Bowman et al. 2013; Petersen et al. 2016) and terrestrial (Bowman et al. 2014; Kemp et al. 2014) proxies indicate a general continuation into LB10 and the SF of the cool-temperate climatic conditions which characterized the Antarctic Peninsula region during the late Maastrichtian, without any major changes. However, palaeontological data are consistent with the hypothesis that biogeochemical cycling and ecosystem function remained disturbed for an extended period.

There is a large drop in species richness immediately above the $\mathrm{K}-\mathrm{Pg}$ boundary, and a transient change in the dominance of taxa is seen throughout LB10 until a horizon dated to about c. $320 \mathrm{kyr}$ after the extinction event (Figs 2, 3). Previously published microfossil evidence from this interval in the Antarctic has shown an increased number of diatom resting spores (Harwood 1988) and repeated blooms of successive opportunistic dinoflagellate taxa, following a considerable drop in diversity after the boundary (Askin 1988; Bowman et al. 2012). Bowman et al. (2014) also noted disturbance in the terrestrial palynoflora in LB10, although no 'fern-spike' has been reported from Antarctica at the $\mathrm{K}-\mathrm{Pg}$ boundary. The apparent recovery of the terrestrial palynoflora occurred towards the top of the LBF and across the unconformity into the SF (Bowman et al. 2014). Huber (1988) demonstrated that foraminifera are rare and poorly preserved
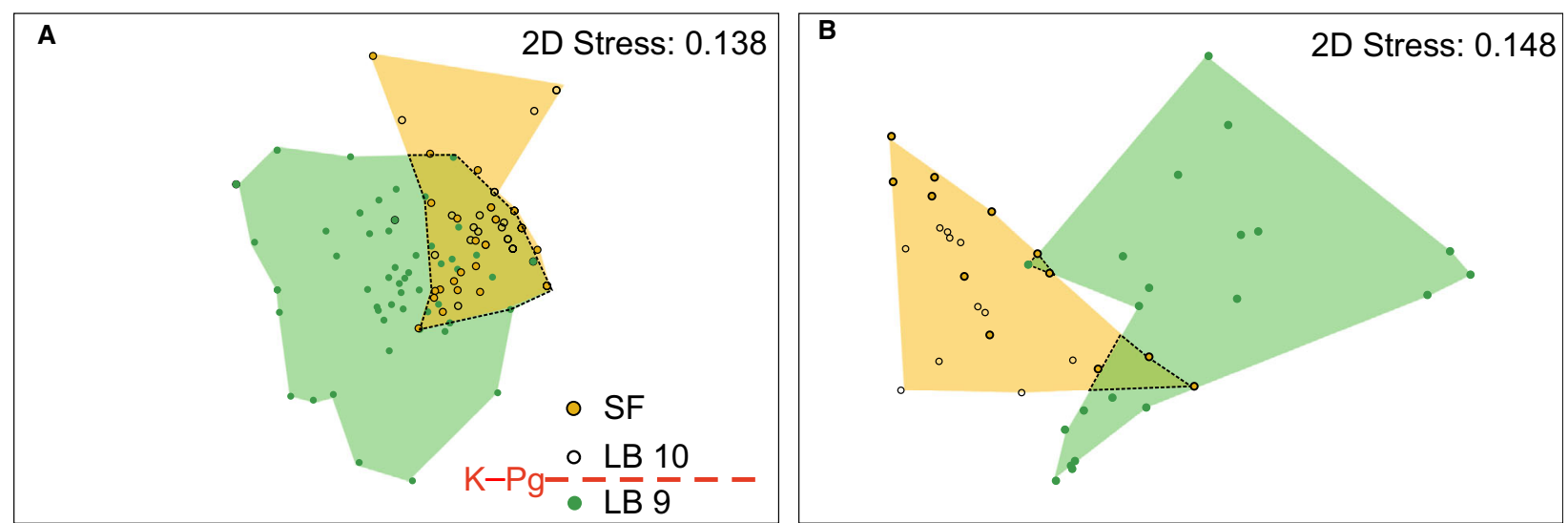

FIG. 6. Nonmetric multidimensional scaling (nMDS) ordination comparing modes of life in Cretaceous and Palaeogene samples. A, ecology based on species numbers from the 1999, 2006 and 2010 BAS field collections. B, ecology based on abundance data, from the 1999, 2006 and 2010 BAS field collections (see Material and Method). 
above the $\mathrm{K}-\mathrm{Pg}$ boundary. The first diagnostic Danian foraminiferal assemblage also occurs at the top of the LBF, $1 \mathrm{~m}$ below the contact with the SF (Huber 1988), although this record may be affected by secondary diagenetic decalcification which is a common issue with calcareous microfossil assemblages in the James Ross Basin (Švábenická et al. 2012).

The increase in benthic molluscan species richness in the upper levels of LB10 dated c. $320 \mathrm{kyr}$ after the mass extinction, along with the maximum post-extinction species richness attained $c .1$ myr after the mass extinction in the SF, appear to represent significant horizons in the biotic recovery of marine ecosystems in Antarctica. The dates associated with these intervals are also significant when comparing these data with recovery from the mass extinction on a global scale. They coincide closely with timing for the staged recovery of ecosystem function and diversity of various taxonomic groups of primary producers (Coxall et al. 2006; Jiang et al. 2010; Vellekoop et al. 2017), and recovery of the global carbon cycle following the collapse of the deep-sea carbon isotope gradient at the K-Pg boundary (D'Hondt et al. 1998; Esmeray-Senlet et al. 2015; Birch et al. 2016; Witts et al. 2018).

Once thought to represent a total global primary productivity collapse following global darkness after the impact event (Arthur et al. 1987), it is likely that the collapse of the deep-sea carbon isotope gradient instead indicates a loss of efficiency of the biological pump, enhanced nutrient cycling in surface waters, and a significant reduction in organic carbon export and burial globally (D'Hondt 2005; Coxall et al. 2006; Alegret et al. 2012). Such a scenario implies that while nutrients were available for planktonic communities (Lowery et al. 2018), benthic communities and taxa may have been locally starved of food (D'Hondt 2005; Esmeray-Senlet et al. 2015; Vellekoop et al. 2017).

Nearshore and shelf ecosystems, such as those in this study, may have been buffered to a degree from the direct effects of an inefficient biological pump. However, the presence of weak isotope gradients and negative excursions in carbon isotopes in numerous shelf settings as well as the deep ocean, suggest the overall effects were felt worldwide during the early Danian regardless of water depth and latitude (Esmeray-Senlet et al. 2015; Vellekoop et al. 2017). In addition, recent data from Seymour Island suggest the collapse of carbon export and organic carbon burial at the $\mathrm{K}-\mathrm{Pg}$ boundary also affected the global sulfur cycle, with a prominent negative excursion in sulfur isotopes from biogenic carbonate within LB10 (Witts et al. 2018). Recovery of the sulfur cycle to pre-extinction values occurred at the same time (c. $320 \mathrm{kyr}$ ) as the initial recovery of the carbon cycle globally (Witts et al. 2018). These recoveries in geochemical proxies occurred on a similar timescale, and coincide stratigraphically with the appearance of new taxa and the initial stages of full ecological recovery in LB10, with a return of epifaunal taxa occurrences (interval iii in Figs 3, 4).

This similarity in the initial recovery times between geochemical cycles, taxonomic and ecological recovery of marine ecosystems, in a variety of locations and palaeoenvironmental settings following the $\mathrm{K}-\mathrm{Pg}$ mass extinction, agrees with the 'Earth System Succession' model, where stabilization of biogeochemical cycles is intimately tied to bottom-upward biotic recovery following severe environmental perturbation (Hull 2015). A similar situation has been hypothesized for the aftermath of other Phanerozoic mass extinction events and may represent a general pattern (Payne \& Clapham 2012; Foster et al. 2017), with the carbon cycle and marine ecosystems re-stabilizing on a similar timescale (Chen \& Benton, 2012; Hull \& Darroch, 2013). In all cases, only when the carbon cycle and the base of the marine food chain is restored, can significant biotic recovery begin.

\section{Ecological recovery from the mass extinction}

Although the degree of taxonomic loss of benthic molluscan faunas was comparable in severity to the northern hemisphere (data herein; Aberhan \& Kiessling 2014; Witts et al. 2016) the shift in ecological dominance across the $\mathrm{K}-\mathrm{Pg}$ boundary in Antarctica was not as marked as at other locations. A greater degree of change in ecological composition between Maastrichtian and Danian communities was recorded at the Brazos River site (USA), Bajada del Jagüel and San Ramón (Argentina) (Fig. 6; cf. Aberhan \& Kiessling 2015, fig. S3). This is consistent with a degree of geographical heterogeneity in the ecological response to the mass extinction event. Ecological trends of $\mathrm{K}-\mathrm{Pg}$ recovery are especially well-studied in the US Gulf Coastal Plain, proximal to the Chicxulub crater (Schulte et al. 2010). Here, early Danian faunas show a dramatic increase in abundance and number of predatory carnivorous taxa, and a replacement of epifaunal sessile suspension feeders by more active suspension feeders in offshore assemblages (Hansen 1988; Sessa et al. 2012). In contrast, shallow subtidal assemblages did not appear to experience significant ecological reorganization following the K-Pg extinction (Sessa et al. 2012).

Only 2 of the 12 modes of life exhibited by benthic molluscs in the section are present in the Maastrichtian but do not occur in the Paleocene of Antarctica. However, they are known from younger Antarctic fossil deposits (Whittle et al. 2011, 2014), and did not disappear during the Paleocene on a global scale (Aberhan \& Kiessling 2014). This is consistent with the hypothesis that global functional diversity is generally retained after mass extinction events, despite severe taxonomic losses 
(Dunhill et al. 2018). There is little evidence for detritusbased benthos (deposit feeders and bottom dwelling predators) preferentially surviving the $\mathrm{K}-\mathrm{Pg}$ extinction in Antarctica or proliferating in its immediate aftermath to the detriment of suspension feeders. This is despite the evidence for limitation of benthic food supply and reduction in carbon export globally, and is contrary to the 'classic' models where deposit feeders survive over suspension feeders discussed by Sheehan \& Hansen (1986) and Sheehan et al. (1996) for primarily North American localities, and Aberhan et al. (2007) in South America.

\section{Palaeoenvironmental factors affecting recovery in Antarctica}

Despite evidence for no significant shift in palaeoenvironment (i.e. water depth) across the $\mathrm{K}-\mathrm{Pg}$ boundary, which could overprint changes in species richness and abundance data caused by the mass extinction event, the change in species richness from the LBF into the SF could be partly driven by an environmental shift from mid-shelf to prodeltaic conditions. There is however, not a significant time gap between the two formations based on biostratigraphical dating and calculations based on the rate of sedimentation (Bowman et al. 2016).

Although the number of benthic molluscan species increases to its highest level in the section in the lower SF, many of the new taxa which occur in this interval have short stratigraphical ranges (Fig. 4). We argue that these ranges are probably artificially truncated because of changes in water depth due to delta progradation or other local palaeoenvironmental perturbations. For example, the frequent presence of ash layers points to repeated ash falls produced by large volcanic eruptions on the adjacent Antarctic Peninsula during the early Danian (Fig. 4). Because of these environmental fluctuations, it is likely that they are not representative of the true stratigraphical distribution of these taxa. In addition, the majority of benthic molluscan species in this study are endemic to the James Ross Basin, and it should be noted that localities of the same age are not known from elsewhere in onshore Antarctica.

\section{Why did some taxa preferentially survive following the} extinction?

One species of bivalve (Lahillia larseni) that survived the extinction has been reported to occur in flood abundance above the $\mathrm{K}-\mathrm{Pg}$ boundary in Antarctica (Crame et al. 2004; Stilwell et al. 2004). This was suggested as a classic signature of 'disaster taxa', opportunists that proliferate in the immediate aftermath of an ecological crisis due to reduced competition and/or vacant ecospace (Harries et al. 1996). Our data show an increase in abundance of Lahillia larseni after the K-Pg mass extinction (see Whittle et al. 2019, suppl. data) and indicate a proliferation of the newly evolved species Struthiochenopus hurleyi and Cucullaea ellioti immediately following the extinction horizon. These taxa were facultatively motile shallow infaunal suspension feeders or slow motile shallow infaunal surface deposit feeders. Lahillia larseni crossed the KPg boundary, whilst Cucullaea ellioti and Struthiochenopus hurleyi had close relatives in the Cretaceous (Cucullaea antarctica and Austroapporhais respectively). This suggests a role for incumbency, which may have been a significant factor in the survival and phased recovery of southern hemisphere marine fauna and floras following the $\mathrm{K}-\mathrm{Pg}$ extinction in a variety of clades (Aberhan \& Kiessling 2014; Schueth et al. 2015). These three taxa remain dominant throughout the following units, until evidence for significant basin shallowing towards the top of the SF, when there is a decrease in the abundance of all taxa, with the exception of the bivalve Pinna, apparently adapted to such shallow water conditions.

It is difficult to ascertain the reason for the local dominance of infaunal taxa during the $c .320$ kyr following the $\mathrm{K}-\mathrm{Pg}$ mass extinction in Antarctica. Buried species may simply have been more sheltered from environmental perturbation on the sea bed or in the overlying water column than epifauna. Infaunal organisms may also have been pre-adapted to the highly seasonal changes unique to this high latitude environment, probably accentuated in the immediate aftermath of the bolide impact by processes such as global darkness (Alvarez et al. 1980) and reduction or change in the quality of food supply to the benthos (Sepúlveda et al. 2009; Alegret et al. 2012; Vellekoop et al. 2017). It is plausible that an adaptation to these conditions was a considerable selective advantage during the earliest Palaeogene.

The aporrhaid gastropod Struthiochenopus hurleyi provides a good example, being particularly abundant after the extinction, making up almost $50 \%$ of the total Danian fossils collected in the BAS sections (Fig. 3) (Whittle et al. 2019). The modern aporrhaid species Aporrhais occidentalis alternates between periods of epifaunal activity in the summer and infaunal quiescence in the winter, although experiments and observations showed no evidence for a causal relationship between temperature change and burrowing (Perron 1978). The switch in life habit may therefore be linked to seasonal productivity; a gastropod adapted to such periods of non-feeding quiescence in a time of reduced benthic food supply might have a selective advantage. A recent study (Moss et al. 2017) also demonstrated that high latitude Cretaceous and Palaeogene bivalves, including several genera which survived and proliferated in LB10 (Lahillia, Cucullaea) (Fig. 3), exhibited lifespans of more than 100 years. It is likely that 
this longevity was due to slow growth rates linked to slow metabolism, and an adaptation to caloric reduction brought about by the limited availability of food supplies in high latitude environments, ultimately driven by the polar light regime. However, some preadaptation to enhanced seasonality could be argued for all members of the Antarctic $\mathrm{K}-\mathrm{Pg}$ marine fauna.

Riedel et al. (2012) showed through in situ experiments that epifauna and predatory taxa are more sensitive to oxygen depletion than infauna. Therefore, the possibility of intermittently anoxic to euxinic conditions on the seafloor and in the water column following the K-Pg mass extinction in Antarctica (Zinsmeister 1998; Witts et al. 2016; Schoepfer et al. 2017) may have led to the preferential survival, and dominance of infaunal organisms following the extinction horizon in this location. Clapham (2017) found that more motile organisms preferentially survived Mesozoic extinctions, suggesting that greater activity and therefore potentially higher respiratory physiology, controlled survival during extinction periods (Clapham 2017). Our data show little change in the taxonomic richness of facultatively motile taxa; however, abundance trends do show an increase in motility during the early Danian.

Many of the local ecological patterns seen in the recovery of the benthic molluscan fauna on Seymour Island are driven by the near-extinction of slow motile epifaunal carnivorous gastropods at the $\mathrm{K}-\mathrm{Pg}$ boundary, and a rapid radiation of taxa belonging to this mode of life in the SF (Figs 4, 5). Gastropods belonging to this mode of life may have been somehow more susceptible to environmental change than others, perhaps for the reasons outlined above, or due to some competitive disadvantage not obvious from fossil occurrence data alone. The rapid diversification of gastropods (15 taxa originating in approximately 600000 years) in the early Paleocene deposits of Seymour Island can be linked to a global event: the rise to dominance in marine molluscan faunas of a single clade, the Neogastropoda (Crame 2013; Crame et al. 2014). These new stratigraphically constrained data from Antarctica would suggest that this radiation was well under way less than 1 myr after the $\mathrm{K}-\mathrm{Pg}$ extinction in the southern hemisphere with the appearance of many new neogastropod taxa in the SF (Stilwell et al. 2004; Crame et al. 2014).

A well-documented shift in dominance in global molluscan faunas from bivalves to gastropods occurs above the K-Pg boundary (Valentine 1969; Vermeij 1977; Sepkoski 2002; Alroy 2010). This occurs over the same timescale in Antarctica, with the rapid speciation of new gastropod taxa in the SF (Fig. 4, and Crame et al. 2014). The patterns seen in the gastropod fauna are in contrast with those exhibited by bivalves, which are dominated by fewer taxa which survived the $\mathrm{K}-\mathrm{Pg}$ extinction (Fig. 4) (Stilwell et al. 2004; Crame et al.
2014). Interestingly, the recovery of benthic molluscan species richness in the early Danian of the SF also appears to include the first representatives of several modern Southern Ocean molluscan genera (Beu 2009; Crame 2013; Crame et al. 2014). This supports the hypotheses that the $\mathrm{K}-\mathrm{Pg}$ extinction was instrumental in resetting the evolutionary stage prior to the evolution of the modern marine fauna (Krug et al. 2009), and that Antarctica may have acted as an evolutionary source rather than a sink during the Palaeogene prior to the onset of glaciation at the Eocene-Oligocene boundary (Crame 2013; Crame et al. 2014).

\section{CONCLUSIONS}

Overall, our data show a complex interplay of local environmental factors and broader global patterns in the recovery from the $\mathrm{K}-\mathrm{Pg}$ mass extinction in Antarctica. The marine recovery in Antarctica is characterized by a shift in abundance and taxonomic richness of benthic molluscan faunas, with infaunal taxa dominating for an initial $320 \mathrm{kyr}$ period of the early Danian. Taxonomic recovery is marked by significant increases in origination and species richness around $320 \mathrm{kyr}$ and 1 myr after the mass extinction. These shifts can be linked to the reestablishment of global biogeochemical cycles and recovery of primary producers over the same timescale worldwide. There is a decoupling of taxonomic and ecological extinction intensity in Antarctica across the K-Pg boundary, and little evidence for the preferential survival of particular ecologies or modes of life following the mass extinction. The degree of ecological change is apparently less than those seen at lower latitudes, which may be explained by a pre-adaptation to seasonally challenging conditions in the Antarctic fauna. The differences in the degree of ecological change between sites supports the hypothesis of geographic heterogeneity in post-extinction ecosystem dynamics.

Acknowledgements. This study is a part of the British Antarctic Survey Polar Science for Planet Earth Programme. We appreciate the help of Hilary Blagbrough with access to BAS collections and technical support. We thank the staff of the Paleontological Research Institute (Ithaca) for assistance with access to the W. J. Zinsmeister collection. This work was funded by NERC (UK) grants NE/I005803/1 and NE/C506399/1, and a PhD scholarship from the University of Leeds to JDW. A Lerner-Gray Research grant from the American Museum of Natural History to RJW is also acknowledged. We thank the anonymous referees who commented on an earlier draft of this manuscript.

Author contributions. RJW and JDW compiled the data, conducted the analyses and wrote the manuscript as joint first authors. RJW, VCB, JAC, JEF and JI collected the specimens. RJW, JDW, VCB, JAC, JEF and JI edited the manuscript. 


\section{DATA ARCHIVING STATEMENT}

Data for this study are available in the Dryad Digital Repository: https://doi.org/10.5061/dryad.v1265j8

Editor. John Jagt

\section{REFERENCES}

ABERHAN, M. and KIESSLING, W. 2014. Rebuilding biodiversity of Patagonian marine molluscs after the end-cretaceous mass extinction. PLoS One, 9, e102629.

_ 2015. Persistent ecological shifts in marine molluscan assemblages across the end-Cretaceous mass extinction. Proceedings of the National Academy of Sciences, 112, 7207-7212.

- WEIDEMEYER, S., KIESSLING, W., SCASSO, R. A. and MEDINA, F. A. 2007. Faunal evidence for reduced productivity and uncoordinated recovery in Southern Hemisphere Cretaceous-Paleogene boundary sections. Geology, 35, 227-230.

ALEGRET, L., THOMAS, E. and LOHMANN, K. C. 2012. End-Cretaceous marine mass extinction not caused by productivity collapse. Proceedings of the National Academy of Sciences, 109, 728-732.

ALROY, J. 2010. The shifting balance of diversity among major animal groups. Science, 329, 1191-1194.

- ABERHAN, M., BOTTJER, D. J., FOOTE, M., FÜRSICH, F. T., HARRIES, P. J., HENDY, A. J. W., HOLLAND, S. M., IVANY, L. C., KIESSLING, W., KOSNIK, M. A., MARSHALL, C. R., McGOWAN, A. J., MILLER, A. I., OLSZEWSKI, T. D., PATZKOWSKY, M. E., PETERS, S. E., VILLIER, L., WAGNER, P. J., BONUSO, N., BORKOW, P. S., BRENNEIS, B., CLAPHAM, M. E., FALL, L. M., FERGUSON, C. A., HANSON, V. L., KRUG, A. Z., LAYOU, K. M., LECKEY, E. H., NÜRNBERG, S., POWERS, C. M., SESSA, J. A., SIMPSON, C., TOMAŠOVÝCH, A. and VISAGGI, C. C. 2008. Phanerozoic trends in the global diversity of marine invertebrates. Science, 321, 97-100.

AlvareZ, L. W., AlvareZ, W., ASARO, F. and MICHEL, H. V. 1980. Extraterrestrial cause for the Cretaceous-Tertiary extinction. Science, 208, 1095-1108.

ARTEMIEVA, N., MORGAN, J. and EXPEDITION 364 SCIENCE PARTY. 2017. Quantifying the release of climate-active gases by large meteorite impacts with a case study of Chicxulub. Geophysical Research Letters, 44, 10180-10188.

ARTHUR, M. A., ZACHOS, J. C. and JONES, D. S. 1987. Primary productivity and the Cretaceous/Tertiary boundary event in the oceans. Cretaceous Research, 8, 43-54.

ASKIN, R. A. 1988. Campanian to Paleocene palynological succession of Seymour and adjacent islands, northeastern Antarctic Peninsula. Geological Society of America Memoirs, 169, 131-153.

BAMBACH, R. K., KNOLL, A. H. and WANG, S. C. 2004. Origination, extinction, and mass depletions of marine diversity. Paleobiology, 30, 522-542.

- BUSH, A. M. and ERWIN, D. H. 2007. Autecology and the filling of ecospace: key metazoan radiations. Palaeontology, 50, $1-22$.
BEU, A. 2009. Before the ice: biogeography of Antarctic Paleogene molluscan faunas. Palaeogeography, Palaeoclimatology, Palaeoecology, 284, 191-226.

BIRCH, H. S., COXALL, H. K., PEARSON, P. N., KROON, D. and SCHMIDT, D. N. 2016. Partial collapse of the marine carbon pump after the Cretaceous-Paleogene boundary. Geology, 44, 287-290.

BOWMAN, V. C., FRANCIS, J. E., RIDING, J. B., HUNTER, S. J. and HAYWOOD, A. M. 2012. A latest Cretaceous to earliest Paleogene dinoflagellate cyst zonation from Antarctica, and implications for phytoprovincialism in the high southern latitudes. Review of Palaeobotany \& Palynology, 171, 40-56.

- 2013. Late Cretaceous winter sea ice in Antarctica? Geology 41, 1227-1230.

— ASKIN, R. A., RIDING, J. B. and SWINDLES, G. T. 2014. Latest Cretaceous-earliest Paleogene vegetation and climate change at the high southern latitudes: palynological evidence from Seymour Island, Antarctic Peninsula. Palaeogeography, Palaeoclimatology, Palaeoecology, 408, 26-47.

- INESON, J., RIDING, J., CRAME, J., FRANCIS, J., CONDON, D., WhitTle, R. and FERRACCIOLI, F. 2016. The Paleocene of Antarctica: biostratigraphy and palaeogeographical implications for the palaeo-Pacific margin of Gondwana. Gondwana Research, 38, 132-148.

BRUGGer, J., FEULnER, G. and PETRI, S. 2017. Baby, it's cold outside: climate model simulations of the effects of the asteroid impact at the end of the Cretaceous. Geophysical Research Letters, 44, 419-427.

BRUSATTE, S. L., BARRETT, P. M., CARRANO, M. T., EVANS, D. C., LLOYD, G. T., MANNION, P. D., NORELL, M. A., PEPPE, D. J., UPCHURCH, P. and WILliAMSON, T. E. 2015. The extinction of the dinosaurs. Biological Reviews, 90, 628-642.

CHEN, Z.-Q. and BENTON, M. J. 2012. The timing and pattern of biotic recovery following the end-Permian mass extinction. Nature Geoscience, 5, 375-383.

CLAPHAM, M. E. 2017. Organism activity levels predict marine invertebrate survival during ancient global change extinctions. Global Change Biology, 23, 1477-1485.

CLARKE, K. R. and WARWICK, R. M. 2001. Change in marine communities: an approach to statistical analysis and interpretation. 2nd edn. PRIMER-E Ltd, Plymouth.

COURTillot, V. and FluteAu, F. 2010. Cretaceous extinctions: the volcanic hypothesis. Science, 328, 973-974.

COXALL, H. K., D'HONDT, S. and ZACHOS, J. C. 2006. Pelagic evolution and environmental recovery after the Cretaceous-Paleogene mass extinction. Geology, 34, 297-300.

CRAME, J. A. 2013. Early Cenozoic differentiation of polar marine faunas. PLoS One, 8, e54139.

- FRANCIS, J. E., CANTRILL, D. J. and PIRRIE, D. 2004. Maastrichtian stratigraphy of Antarctica. Cretaceous Research, 25, 411-423.

- BEU, A. G., INESON, J. R., FRANCIS, J. E., WHITTLE, R. J. and BOWMAN, V. C. 2014. The early origin of the Antarctic marine fauna and its evolutionary implications. PLoS One, 9, e114743. 
D'HONDT, S. 2005. Consequences of the Cretaceous/Paleogene mass extinction for marine ecosystems. Annual Review of Ecology, Evolution, \& Systematics, 36, 295-317.

- DONAGHAY, P., ZACHOS, J. C., LUTTENBERG, D. and LINDINGER, M. 1998. Organic carbon fluxes and ecological recovery from the Cretaceous-Tertiary mass extinction. Science, 282, 276-279.

DONOVAN, M. P., IGLESIAS, A., WILF, P., LABANDEIRA, C. C. and CÚNEO, R. 2016. Rapid recovery of Patagonian plant-insect associations after the end-Cretaceous extinction. Nature Ecology \& Evolution, 1, 12.

DUNHILl, A. M., FOSTER, W. J., SCIBERRAS, J. and TWITCHETT, R. J. 2018. Impact of the Late Triassic mass extinction on functional diversity and composition of marine ecosystems. Palaeontology, 61, 133-148.

ELLIOT, D. H., ASKIN, R. A., KYTE, F. T. and ZINSMEISTER, W. J. 1994. Iridium and dinocysts at the Cretaceous-Tertiary boundary on Seymour Island, Antarctica: implications for the K-T event. Geology, 22, 675-678.

ESMERAY-SENLET, S., WRIGHT, J. D., OLSSON, R. K., MILlER, K. G., BROWNING, J. V. and QUAN, T. M. 2015. Evidence for reduced export productivity following the Cretaceous/Paleogene mass extinction. Paleoceanography, 30, 718-738.

FOSTER, W. J., DANise, S., PRICE, G. D. and TWITCHETT, R. J. 2017. Subsequent biotic crises delayed marine recovery following the late Permian mass extinction event in northern Italy. PLoS One, 12, e0172321.

GRADSTEIN, F. M., OGG, J. G., SCHMitZ, M. D. and OGG, G. M. eds. 2012. The Geological Time Scale 2012. Elsevier, 2 vols, $1144 \mathrm{pp}$.

HANSEN, T. A. 1988. Early Tertiary radiation of marine molluscs and the long-term effects of the Cretaceous-Tertiary extinction. Paleobiology, 14, 37-51.

HARRIES, P. J., KAUFFMAN, E. G. and HANSEN, T. A. 1996. Models for biotic survival following mass extinction, in HART, M.B. Biotic recovery from mass extinction events. Geological Society, London, Special Publications, 102, $41-60$.

HARWOOD, D. M. 1988. Upper Cretaceous and lower Paleocene diatoms and silicoflagellate biostratigraphy of Seymour Island, eastern Antarctic Peninsula. Geological Society of America Memoirs, 169, 55-129.

HUBER, B. T. 1988. Upper Campanian-Paleocene foraminifera from the James Ross Island region, Antarctic Peninsula. Geological Society of America Memoirs, 169, 163-252.

HULL, P. M. 2015. Life in the aftermath of mass extinctions. Current Biology, 25, R941-R952.

— and DARROCH, S. A. F. 2013. Mass extinction and the structure and function of ecosystems. The Paleontological Society Papers, 19, 1-42.

— NORRIS, R. D., BRALOWER, T. J. and SCHUETH, J. D. 2011. A role for chance in marine recovery from the end-Cretaceous extinction. Nature Geoscience, 4, 856-860.

JABLONSKI, D. and RAUP, D. M. 1995. Selectivity of endcretaceous bivalve extinctions. Science, 268, 389-391.

JIANG, S., BRALOWER, T. J., PATZKOWSKY, M. E., KUMP, L. R. and SCHUETH, J. D. 2010. Geographic controls on nannoplankton extinction across the Cretaceous/ Palaeogene boundary. Nature Geoscience, 3, 280-285.

— CHEN, X. and BERNAOLA, G. 2018. Environmental controls on calcareous nannoplankton response to the Cretaceous/Paleogene mass extinction in the Tethys realm. Palaeogeography, Palaeoclimatology, Palaeoecology, 515, 134-142.

KEller, G., ADATTE, T., PARDO, A., BAJPAI, S., KHOSLA, A. and SAMANT, B. 2010. Cretaceous extinctions: evidence overlooked. Science, 328, 974-975.

KEMP, D. B., ROBINSON, S. A., CRAME, J. A., FRANCIS, J. E., INESON, J., WHitTle, R. J., BOWMAN, V. and O'BRIEN, C. 2014. A cool temperate climate on the Antarctic Peninsula through the latest Cretaceous to early Paleogene. Geology, 42, 583-586.

KRUG, A. Z., JABLONSKI, D. and VALENTINE, J. W. 2009. Signature of the end-cretaceous mass extinction in the modern biota. Science, 323, 767-771.

LANDMAN, N. H., GOOLAERTS, S., JAGT, J. W. M., JAGT-YAZYKOVA, E. A., MACHALSKI, M. and YACOBUCCI, M. M. 2014. Ammonite extinction and nautilid survival at the end of the Cretaceous. Geology, 42, 707710.

LAWVER, L. A., GAHAGAN, L. M. and COFFIN, M. F. 1992. The development of paleoseaways around Antarctica. 7-30. In KENNETT, J. P. and WARNKE, D. A. (eds). The Antarctic paleoenvironment: A perspective on global change. Part 1. American Geophysical Union, Antarctic Research Series, 56.

LOCKWOOD, R. 2004. The K/T event and infaunality: morphological and ecological patterns of extinction and recovery in veneroid bivalves. Paleobiology, 30, 507-521.

LONGRICH, N. R., BHULLAR, B.-A. and GAUTHIER, J. A. 2012. Mass extinction of lizards and snakes at the Cretaceous-Paleogene boundary. Proceedings of the National Academy of Sciences, 109, 21396-21401.

LOWERY, C. M., BRALOWER, T. J., OWENS, J. D., RODRÍGUEZ-TOVAR, F. J., JONES, H., SMIT, J., WHALEN, M. T., CLAEYS, P., FARLEY, K., GULICK, S. P. S., MORGAN, J. V., GREEN, S., ChenOT, E., CHRistesON, G. L., COCKELL, C. S., COOLEN, M. J. C., FERRIÈrE, L., GEBHARDT, C., GOTO, K., KRING, D. A., LOFI, J., OCAMPO-TORRES, R., PEREZ-CRUZ, L., PICKERSGILL, A. E., POELCHAU, M. H., RAE, A. S. P., RASMUSSEN, C., REBOLlEDO-VIERYA, M., RILlER, U., SATO, H., TIKOO, S. M., TOMIOKA, N., URRUTIA-FUCUGAUCHI, J., VELLEKOOP, J., WitTMAN, A., XIAO, L., YAMAGUCHI, K. E. and ZYLBERMAN, W. 2018. Rapid recovery of life at ground zero of the end-Cretaceous mass extinction. Nature, 558, 288-291.

MACELLARI, C. E. 1988. Stratigraphy, sedimentology, and palaeoecology of Upper Cretaceous/Paleocene shelf-deltaic sediments of Seymour Island. Geological Society of America, Memoir, 169, 25-53.

MARENSSI, S., SANTILlANA, S. and BAUER, M. 2012. Estratigrafía, petrografía sedimentaria y procedencia de las formaciones Sobral y Cross Valley (Paleoceno), isla Marambio (Seymour), Antártica. Andean Geology, 39, 67-91. 
MONTES, N., NOZAL, F., SANTILlANA, S., MARENSSI, S. A. and OLIVERO, E. B. 2010. Mapa geológico de la Isla Marambio (Seymour). Escala 1:20,000. Instituto Geológico y Minero de España, Instituto Antártico Argentino, y Centro Austral de Investigaciones Científicas Argentina.

MOSS, D. K., IVANY, L. C., SILVER, R. B., SCHUE, R. B. and ARTRUC, E. G. 2017. High-latitude settings promote extreme longevity in fossil marine bivalves. Paleobiology, 43, 365-382.

OGG, J. G., HINNOV, L. A. and HUANG, C. 2012. Ch. 27 Cretaceous. 793-853. In GRADSTEIN, F. M., OGG, J. G., SCHMiTZ, M. D. and OGG, G. M. (eds). The Geological Time Scale 2012. Elsevier, Amsterdam, 2 vols, 1144 pp.

OLIVERO, E. B. 2012. Sedimentary cycles, ammonite diversity and palaeoenvironmental changes in the Upper Cretaceous Marambio Group, Antarctica. Cretaceous Research, 34, 348-366.

— PONCE, J. J. and MARTinioni, D. R. 2008. Sedimentology and architecture of sharp based tidal sandstones in the upper Marambio Group, Maastrichtian of Antarctica. Sedimentary Geology, 210, 11-26.

PAYNE, J. L. and CLAPHAM, M. E. 2012. End-Permian mass extinction in the oceans: an ancient analog for the twenty-first century? Annual Review of Earth \& Planetary Science, 40, 89-111.

PERRON, F. E. 1978. Seasonal burrowing behaviour and ecology of Aporrhais occidentalis (Gastropoda: Strombacea). The Biological Bulletin, 154, 463-471.

PETERSEN, S. V., DUTTON, A. and LOHMANN, K. C. 2016. End-Cretaceous extinction in Antarctica linked to both Deccan volcanism and meteorite impact via climate change. Nature Communications, 7, 12079.

RAUP, D. M. and JABLONSKI, J. J. 1993. Geography of endcretaceous marine bivalve extinctions. Science, 260, 971-973.

- and SEPKOSKI, J. J. 1982. Mass extinctions in the marine fossil record. Science, 215, 1501-1503.

RENNE, P. R., DEINO, A. L., HILGEN, F. J., KUIPER, K. F., MARK, D. F., MITCHELL, W. S., MORGAN, L. E., MUNDIL, R. and SMIT, J. 2013. Time scales of critical events around the Cretaceous-Paleogene boundary. Science, 339, 684-687.

RIEDEL, B., ZUSCHIN, M. and STACHOWITSCH, M. 2012. Tolerance of benthic macrofauna to hypoxia and anoxia in shallow coastal seas: a realistic scenario. Marine Ecology Progress Series, 458, 39-52.

SCHOENE, B., EDDY, M. P., SAMPERTON, K. M., BREHNIN KELLER, C., KELLER, G., ADATTE, T. and KHADRI, S. F. R. 2019. U-Pb constraints on pulsed eruption of the Deccan Traps across the end-Cretaceous mass extinction. Science, 363, 862-866.

SCHOEPFER, S. D., TOBIN, T. S., WITTS, J. D. and NEWTON, R. J. 2017. Intermittent euxinia in the high-latitude James Ross Basin during the latest Cretaceous and earliest Paleocene. Palaeogeography, Palaeoclimatology, Palaeoecology, 477, 40-54.

SCHUETH, J. D., BRALOWER, T. J., JIANG, S. and PATZKOWSKY, M. E. 2015. The role of regional survivor incumbency in the evolutionary recovery of calcareous nannoplankton from the Cretaceous/Paleogene $(\mathrm{K} / \mathrm{Pg})$ mass extinction. Paleobiology, 41, 661-679.

SChulte, P., Alegret, L., ARenillas, I., ARZ, J. A., BARTON, P. J., BOWN, P. R., BRALOWER, T. J., CHRisteson, G. L., ClAEYS, P., COCKELL, C. S., COLlins, G. S., DEUTSCH, A., GOLDIN, T. J., GOTO, K., GRAJALES-NISHIMURA, J. M., GRIEVE, R. A. F., GULICK, S. P. S., JOHNSON, K. R., KIESSLING, W., KOEBERL, C., KRING, D. A., MACLEOD, K. G., MATSUI, T., Melosh, J., MONTANARI, A., MORGAN, J. V., NEAL, C. R., NICHOLS, D. J., NORRIS, R. D., PIERAZZO, E., RAVIZZA, G., REBOLLEDO-VIEYRA, M., REIMOLD, W. U., ROBIN, E., SALGE, T., SPEIJER, R. P., SWEET, A. R., URRUTIAFUCUGAUCHI, J., VAJDA, V., WHALEN, M. T. and WILLUMSEN, P. S. 2010. The Chicxulub asteroid impact and mass extinction at the Cretaceous-Paleogene boundary. Science, 327, 1214-1218.

SEPKOSKI, J. J. 2002. A compendium of fossil marine animal genera. Bulletins of American Paleontology, 363, 1-560.

SEPÚlVEDA, J., WENDLER, J. E., SUMMONS, R. E. and HINRICHS, K.-U. 2009. Rapid resurgence of marine productivity after the Cretaceous-Paleogene mass extinction. Science, 326, 129-132.

SESSA, J. A., BRALOWER, T. J., PATZKOWSKY, M. E., HANDLEY, J. C. and IVANY, L. C. 2012. Environmental and biological controls on the diversity and ecology of Late Cretaceous through early Paleogene marine ecosystems in the U.S. Gulf Coastal Plain. Paleobiology, 38, 218-239.

SHEEHAN, P. M. and HANSEN, T. A. 1986. Detritus feeding as a buffer to extinction at the end of the Cretaceous. Geology, 14, 868-870.

— COOROUGH, P. J. and FASTOVSKY, D. E. 1996. Biotic selectivity during the K/T and Late Ordovician extinction events. Geological Society of America, Special Papers, 307, 477-489.

SIBERT, E. C., HULL, P. M. and NORRIS, R. D. 2014. Resilience of Pacific pelagic fish across the Cretaceous/Palaeogene mass extinction. Nature Geoscience, 7, 667-670.

SOSA-MONTES DE OCA, C., MARTÍNEZ-RUIZ, F. and RODRÍGUEZ-TOVAR, F. J. 2013. Bottom-water conditions in a marine basin after the Cretaceous-Paleogene impact event: timing the recovery of oxygen levels and productivity. PLoS One, 8, e82242.

SPRAIN, C. J., RENNE, P. R., CLEMENS, W. A. and WILSON, G. P. 2018. Calibration of chron C29r: new highprecision geochronologic and paleomagnetic constraints from the Hell Creek region, Montana. Geological Society of America Bulletin, 130, 1615-1644.

—— VANDERKLUYSEN, L., PANDE, K., SELF, S. and MITTAL, T. 2019. The eruptive tempo of Deccan volcanism in relation to the Cretaceous-Paleogene boundary. Science, 363, 866-870.

STILWELL, J. D., ZINSMEISTER, W. J. and OLEINIK, A. E. 2004. Early Paleocene Mollusks of Antarctica: systematics, paleoecology and paleobiogeographic significance. Bulletins of American Paleontology, 367, 1-89. 
ŠVÁBENICKÁ, L., VODRÁ ŽKA, R. and NYVLT, D. 2012. Calcareous nannofossils from the upper Cretaceous of northern James Ross Island, Antarctica: a pilot study. Geological Quarterly, 56, 765-772.

TOBIN, T. S. 2017. Recognition of a likely two phased extinction at the K-Pg boundary in Antarctica. Scientific Reports, 7, 16317.

- WARD, P. D., STEIG, E. J., OLIVERO, E. B., HILBURN, I. A., MITChelL, R. N., DiAMOND, M. R., RAUB, T. D. and KIRSCHVINK, J. L. 2012. Extinction patterns, $\delta 18 \mathrm{O}$ trends, and magnetostratigraphy from a southern high-latitude Cretaceous-Paleogene section: links with Deccan volcanism. Palaeogeography, Palaeoclimatology, Palaeoecology, 350-352, 180-188.

TOSOLINI, A.-M. 2017. North-South recovery divide. Nature Ecology \& Evolution, 1, 33.

VALENTINE, J. W. 1969. Patterns of taxonomic and ecological structure of the shelf benthos during Phanerozoic time. Palaeontology, 12, 684-709.

VELLEKOOP, J., ESMERAY-SENLET, S., MILLER, K. G., BROWNING, J. V., Sluijs, A., VAN DE SCHOOTBRUGGE, B., DAMSTÉ, J. S. S. and BRINKHUIS, H. 2016. Evidence for Cretaceous-Paleogene boundary bolide "impact winter" conditions from New Jersey, USA. Geology, 44, 619-622.

WOELDERS, L., AÇIKALIN, S., SMIT, J., VAN DE SCHOOTBRUGGE, B., YILMAZ, I. Ö., BRINKHUIS, H. and SPEIJER, R. P. 2017. Ecological response to collapse of the biological pump following the mass extinction at the Cretaceous-Paleogene boundary. Biogeosciences, 14, 885-900.

VAN HELMAND, N. A. G. M., GALEOTTI, S., SMIT, S., SLOMP, C. P., BRINKHUIS, P., CLAEYS, P. and SPEIJER, R. P. 2018. Shelf hypoxia in response to global warming after the Cretaceous-Paleogene boundary impact. Geology, 46, 683-686.

VERMEIJ, G. J. 1977. The Mesozoic marine revolution: evidence from snails, predators, grazers. Paleobiology, 3, 245-258.
WHitTle, R. J., LINSE, K. and GRIfFiThS, H. J. 2011. The fossil record of Limopsis (Bivalvia: Limopsidae) in Antarctica and the southern high latitudes. Palaeontology, 54, 935-952.

QUAGLiO, F., GRIFFithS, H. J., LINSE, K. and CRAME, J. A. 2014. The Early Miocene Cape Melville Formation fossil assemblage and the evolution of modern Antarctic marine communities. Naturwissenschaften, 101, 47-59.

WITTS, J., BOWMAN, V., CRAME, A., FRANCIS, J. and INESON, I. 2019. Data from: Nature and timing of biotic recovery in Antarctic benthic marine ecosystems following the Cretaceous-Palaeogene mass extinction. Dryad Digital Repository. https://doi.org/10.5061/dryad. v1265j8

WITTS, J. D., BOWMAN, V. C., WIGNALl, P. B., CRAME, J. A., FRANCIS, J. E. and NEWTON, R. J. 2015. Evolution and extinction of Maastrichtian (Late Cretaceous) cephalopods from the López de Bertodano Formation, Seymour Island, Antarctica. Palaeogeography, Palaeoclimatology, Palaeoecology, 418, 193-212.

- Whittle, R. J., Wignall, P. B., CRAMe, J. A., FRANCIS, J. E., NEWTON, R. J. and BOWMAN, V. C. 2016. Macrofossil evidence for a rapid and severe CretaceousPaleogene mass extinction in Antarctica. Nature Communications, 7, 11738.

- NEWTON, R. J., MILLS, B. J. W., WIGNALL, P. B., BOTTRELL, S. H., HALL, J. L. O., FRANCIS, J. E. and CRAME, J. A. 2018. The impact of the Cretaceous-Paleogene (K-Pg) mass extinction event on the global sulfur cycle: evidence from Seymour Island, Antarctica. Geochimica et Cosmochimica Acta, 230, 17-45.

ZINSMEISTER, W. J. 1998. Discovery of fish mortality horizon at the K-T boundary on Seymour Island: re-evaluation of events at the end of the Cretaceous. Journal of Palaeontology, 72, 556-571. 